\title{
Exploratory Analysis of Entrepreneurship Education in the Jamshoro Public Universities: A Descriptive Study
}

\author{
Aasma Solangi , Adnan Pitafi \\ Mehran University Institute of Science, Technology and Development, Pakistan \\ (Mehran University of Engineering and Technology, Jamshoro, Sindh, Pakistan) \\ asmasolangi19@gmail.com, adnan.pitafi@faculty.muet.edu.pk, adnanpitafi@gmail.com
}

\begin{abstract}
The purpose of this study is to explore entrepreneurship education courses offered by public universities of the Jamshoro higher education institutions (HEIs). It examines the scope and the existing status of entrepreneurship in the Jamshoro public universities. Data were based on secondary data taken from official websites, prospectus, departmental reports and universities' policy documents of the public universities of the Jamshoro Higher, included three public universities by examining their curricula and exploring the status of entrepreneurship of the selected sample from these universities. The results of this study indicated the public universities of the Jamshoro higher education city, just one core course on entrepreneurship was offered to some departments. Furthermore entrepreneurship programs were extremely rare. As a result, this research may encourage policymakers and universities to develop an effective and appropriate syllabus to fill the gap in existing curriculum of not only entrepreneurship but other courses as well.
\end{abstract}

\section{Keywords:}

Entrepreneurial Ecosystem, Entrepreneurship Education, Entrepreneurial Universities, Public universities, Jamshoro higher education city

\section{Introduction}

Over the last 15 years, the global economy has created different methods to utilize the youth talents towards the creations of new enterprises Hitt and Reed (2000). Today's, Career choice is a big development challenge for youngster and difficult to decide which career path should take and purse desired career, but it is an important decision for every youth. Graduates of HEIs are facing difficult challenges in placing themselves in their selected career. This is due to the rising job challenges and employers' expectations, where HEIs graduates are not evaluated just in term the academic qualifications perspective, but also in the term value added skills and capabilities Iswati and Hastuti (2021).

Nowaays unemployment is one of the serious socioeconomic challenges of many countries including Pakistan. The unemployment rate has become a national concern and every year the number of unemployed graduates is increasing Setiawan, Fattah, and Puspitaningrum (2019). However, Entrepreneurship is remedy to reduce the rate of unemployment among the youngster, especially among the (HEIs) higher education institutions. Today's entrepreneurship is mostly associated with bearing risk and innovation. The most important pioneer in the field, Joseph Schumpeter, views innovation as a demanding link between economic growth and entrepreneurship Śledzik (2013). Entrepreneurship is the one of the global growing topic areas, with increasing interest due to its ability to connect the practices of current business with theories of academic. Entrepreneurship education gives students a deep understanding of business, including its purpose, structure, and how it interacts with society as a whole. As a result, it aids in the transmission of abilities that may be taught through an educational system, which can assist individuals build an inventive strategy Klapper and Love (2004). Entrepreneurial education should begin earlier in the educational system, namely at the school level, according to Kroon and Meyer (2001)since it strengthens and prepares students to pursue a career in business after graduation. According to Amanuddin Shamsuddin et al.( 2018), students are more expected to start a business if they had previously engaged in some form of entrepreneurial activity. However the according to previous research, $40 \%$ of students who took entrepreneurship as a course went on to start their own business/venture. Entrepreneurs are seen to have the ability to produce the economic growth of the country through creating the jobs for themselves and others. If someone who take entrepreneurship as their career, they can attain financial independence and also contribute to the economy through the job creation, innovation and development $\&$ growth.

Many nations have begun to incorporate entrepreneurship education courses into their college and university curricula Fayolle, Gailly, and Lassas-Clerc (2006). While acknowledging the importance of entrepreneurial education in the promotion of the country's overall growth and progress, Pakistan's Higher Education Commission (HEC) has taken the initiative to establish centers of Entrepreneurship and Development 
across Pakistan, especially in higher education institutions. In Pakistan, there are total135 universities 61 are private and 74 are public and 1,993 universities affiliated with the Pakistan Higher Education Commission (SIU; HEC, 2012; HEC, 2013). On the other hand, universities lack entrepreneurial staff and faculty; as a result, only a few universities in Pakistan, such as the Islamic College, Lahore University of Management Sciences (LUMS), and Institute of Business Administration (IBA) provide entrepreneurship-related courses in their undergraduate and postgraduate programs. In addition, the Institute of Business Administration (IBA), in collaboration with other public sector institutions, is working hard to develop a Centre of Entrepreneurship. According to the 2016 National Business Accreditation Council, 117 business universities provide courses on how to start and run a business; nevertheless, the schools are failing to meet the demands of students and the business sector. Entrepreneurial education is lacking in Pakistani colleges, and it should be introduced as a separate specialization under Management Education umbrella. Since a result, suitable methods must be followed, as entrepreneurial education would offer stability and sustainability to Pakistan's economic development.

There are three basic ways in which entrepreneurship fosters advancement and growth. The first step is to raise awareness and convey information, which is a dynamic instrument for the country's economic advancement and growth. Organizations must improve their capacity to learn new tools and accept ideas from a variety of groups. The second approach to improve in entrepreneurship is to increase enterprise and competition in society, which helpful in the financial advancement. The number of organizations is growing every day, which is accelerating the creation of new ideas and competitive innovation. Various groups may be able to aid in the adoption of new and creative ways of leading business and achieving economic stability Freytag and Thurik (2010)The third approach to become economically powerful is to build entrepreneurial capital by creating competition among different businesses. Entrepreneurship has direct linked with economic and social development of the country. As a result, entrepreneurship is becoming increasingly popular. The Higher Education Commission has recognized its importance in raising public knowledge about entrepreneurship and fostering professionalism among individuals in order to improve their standard of life. As a result, the government's involvement in enabling entrepreneurship is critical, but unfortunately, in the past, it has played a more negative than positive role. Because of the government's policies and regulations, Pakistani entrepreneurship has suffered greatly. As a result, entrepreneurship in Pakistan never flourished as it should have, Therefore the purpose of this study was to explore the entrepreneurship education course offered by the three public universities in the Jamshoro higher education city.

\section{Literature Review}

Entrepreneurial education is seen as a driving force that promotes economic growth and immunizes individuals with business skills in preparation for the formation and valuation of a company venture Kirkley (2016). Furthermore, it is regarded as a program that concentrates on the start-up and development of businesses within the state-defined norms and regulations Noor, Md. Isa, and Mohd Nor (2020) Entrepreneurial education is significant because it provides students with the skills and information required to start a innovative business venture, as well as inspiring individuals to start their own business by increasing their self-confidence Khan (2008) Haque, 2007; Kuratko (2005); Nabi, G. and Holden (2008), Asghar (2019)The Worldwide universities, particularly in emerging countries, are working hard to promote entrepreneurial education by establishing and constructing innovative curriculum that include the most recent developments in the area (Krueger, B. A. \& Lindahl (2001); Kuratko (2005); Tanveer, Muhammad and Karim, Asif Mahbub Dr. (2019)

According to the estimates, significant progress has been made in this sector in the United States and Europe. Entrepreneurial education has provided 277 endowed posts, over 2,200 courses at over 1,600 schools, 44 academic publications, and the conventional of management journals devoting more to the area of entrepreneurship, much as it has done in the United States Asghar (2019). It's perfect evidence that education of entrepreneurship can be taught, and it disproves the notion that entrepreneurs are born rather than produced Nabi, G. and Holden (2008); Anjum, T., Ramzani, S. R., \& Nazar (2020)). According to Drucker (1985), a famous management theorist of the twentieth century, "the entrepreneurial mystique" is "not mystical, not God-given, and has no genetic relation." A discipline may be learned by anyone. Higher Education Institutions play a key role in fostering an entrepreneurial culture and emphasizing entrepreneurial education by helping to inspire students from many disciplines to pursue entrepreneurship Shah and Soomro (2017). Universities educate students the skills and strategies for starting a firm, as well as assisting in the development of legislation and infrastructure supporting entrepreneurship. Higher Education Institutions should emphasize this technique, emphasizing that a graduate is more than just a job seeker, but also a job creator Schulte( 2004); Tanveer, Muhammad and Karim, Asif Mahbub Dr. (2019)

Many academics argue that entrepreneurship courses not only educate students with fundamental entrepreneurial information and skills, but also help them develop a favourable attitude toward entrepreneurship. Entrepreneurs must have the essential abilities to cope with business difficulties in order to prosper. Improved abilities can boost students' confidence in business and enhance their chances of success. According Marcati, A., This work is licensed under a Creative Commons Attribution-ShareAlike 4.0 International License. 
Guido, G., Peluso, A.M. (2008), entrepreneurship education allows students to examine the variables that contribute to business failure and prevent making the similar mistakes. Entrepreneurship education has the ability to change how people think about business failure and entrepreneurship. According to Donckels (1991); Johannisson (1991); Kirkley (2017), entrepreneurial education may legitimize entrepreneurship as a feasible career choice and create entrepreneurial culture among students. Based on an empirical research of 17 countries students, Kuttim, M., Kallaste, M., Venesaar, U. and Kiis (2014)demonstrated that contributors in entrepreneurship education had higher entrepreneurial ambitions. In addition Souitaris, V., Zerbinati, S. and AlLaham (2007)discovered that entrepreneurship programs increased total entrepreneurial intention due to psychological inspiration, based on an empirical study of science and engineering students. Noel (2001)also discovered that graduate students who majored in entrepreneurship had higher aspirations to establish their own firms, claiming that education might influence self-efficacy (Gist, M.E. and Mitchell 1992).

\section{Research Gap}

In today's world, many scholars have been given a lot of attention to entrepreneurship (Ratten and Jones (2021)In Pakistan, the status of entrepreneurship education is still not particularly encouraging. While for more than two decades HEIs have been offering entrepreneurship education, but still People are unfamiliar with this discipline of education and it is considered an alien subject in Pakistan. University graduates are less ready to become entrepreneurs. Entrepreneurship education has been failed to influence students to involve in entrepreneurship activities. This was also confirmed by Anon (2005), whose research has shown that graduates who have become entrepreneurs have done so through unintended career pathways, entering occupational while waiting to find employment in order to gain experience. Around a decade ago, Pakistan's Higher Education Commission (HEC) recognized the importance of incorporating entrepreneurship education into higher education in order to keep up with changing international movements and trends. It is still limited to one or two courses at the undergraduate and post-graduate levels in Pakistan. However, given the current status of entrepreneurship, it is clear that making it functional and efficient for the country's economic and social growth would be a difficult challenge. The Focus of this study was to explore the status of entrepreneurship education course offered by the three public universities in the Jamshoro higher education city.

\subsection{Research Question}

1. What is the status of entrepreneurship education of the three public universities in the Jamshoro higher education city?

\subsection{Objective Of The Study}

1. To explore the entrepreneurship education course offered by the three public universities in the Jamshoro Higher education city.

\section{Methodology}

The following research consists of Quantitative approach. The data were collected from secondary data taken from the existing literature, official websites, prospectus, departmental reports and universities' policy documents of the public universities in the Jamshoro higher education city in order to explore the entrepreneurship education courses that offered to the students of the Jamshoro higher education city. The secondary data is the assessment of the data that has been collected. This data is inexpensive and conveniently available, and it offers a comprehensive contextual on a given study area Andersen, J. P., Prause, J., \& Silver (2011)As a result, secondary data can be used for a variety of purposes, such as solving a research problem or providing a stronger explanation for an ambiguous topic Boslaugh (2007)However, the secondary data gathering has several advantages over the primary data. Secondary data involve access to current information that is less time demanding than primary data, or it might be seen as legitimate and reliable data since it was obtained by an experienced researcher, official websites, prospectuses and departmental reports.

The universities under the studied

1) Mehran University of Engineering \& Technology, Jamshoro (MUET)

2) University of Sindh (UOS)

3) Liaquat University of Medical and Health sciences (LUMHS) 


\section{Results And Discussion}

To explore the entrepreneurial education courses in the Jamshoro public universities, the results and discussion of study is provided in tabular form and presented descriptively.

According to the results of the Jamshoro universities, only Mehran University of Engineering and Technology (MUET) has offered an entrepreneurship course to more departments, as shown in Table 1. MUET has a total of 24 departments, 16 departments, of which offer an entrepreneurship course to the students.

Table 1.1 lists the names of all departments of Mehran University of Engineering and Technology that offered entrepreneurship courses. The question arises here, why all departments do not provide an entrepreneurship course to their students?

Table 1. Mehran University of Engineering \& Technology

Mehran University of Engineering \& Technology

(MUET)

\begin{tabular}{|c|c|c|c|c|c|c|c|c|}
\hline $\begin{array}{l}\text { Establishme } \\
\text { nt year }\end{array}$ & $\begin{array}{l}\text { No } \\
\text { of } \\
\text { facul } \\
\text { ty }\end{array}$ & $\begin{array}{l}\text { No of } \\
\text { Dept. }\end{array}$ & $\begin{array}{c}\text { Is } \\
\text { Entepreneursh } \\
\text { ip offered as } \\
\text { specialized } \\
\text { subject? }\end{array}$ & $\begin{array}{c}\text { Is } \\
\text { Entrepreneurs } \\
\text { hip offered as } \\
\text { a core Course? }\end{array}$ & $\begin{array}{l}\text { ORIC } \\
\text { Dept. }\end{array}$ & $\begin{array}{c}\text { No of } \\
\text { incubators }\end{array}$ & $\begin{array}{l}\text { No of } \\
\text { Start-up }\end{array}$ & $\begin{array}{l}\text { No of } \\
\text { Patents }\end{array}$ \\
\hline July 1976 & 4 & 24 & No & $\begin{array}{c}\text { Yes } \\
\text { Entrepreneurs } \\
\text { hip course } \\
\text { offered in } 16 \\
\text { departments of } \\
\text { bachelors }\end{array}$ & $\begin{array}{c}\text { Yes } \\
\text { Availab } \\
\text { le }\end{array}$ & $\begin{array}{l}2 \text { Namely; } 1 \\
\text { Research, } \\
\text { innovation \& } \\
\text { commercializat } \\
\text { ion 2: Science } \\
\& \text { Technology } \\
\text { park }\end{array}$ & $\begin{array}{l}\text { Five } \\
\text { Sart-up } \\
\text { compan } \\
\text { ies } \\
\text { register } \\
\quad \text { ed }\end{array}$ & $\begin{array}{l}14 \\
\text { Patenrs } \\
\text { register } \\
\quad \text { ed }\end{array}$ \\
\hline
\end{tabular}

Table 2. Mehran University of Engineering and Technology (MUET)

\begin{tabular}{cc}
\hline SR\# & MUET DEPARTMENTS \\
\hline 1 & Department of Civil Engineering \\
Department of Environmental \\
Engineering \\
3 & Department of Computer System \\
Department of Electronic & Engineering \\
4 & Department of Software Engineering \\
5 & Department of Telecommunication \\
6 & Department of Chemical Engineering \\
7 & Department of Industrial Engineering \\
8 & Department of Mechatronic \\
9 & Engineering \\
& Department of Metallurgy \& \\
10 & Material \\
11 & Department of Textile \\
12 & Bachelor of Business \\
& Administration \\
13 & Bachelor Studies in English \\
14 & Bachelor Science in Garments \\
& manufacturing \\
15 & Bachelor of Science in Computer \\
& Science \\
16 & Bachelor Studies in Environmental \\
& Science \\
\hline
\end{tabular}

Source:

Mehran University of Engineering \&Technology, (2021).prospectus. URL:

http://www.admissions.muet.edu.pk/prospectus/Prospectus\%202021-22\%20(Revised).pdf https://www.muet.edu.pk/

This work is licensed under a Creative Commons Attribution-ShareAlike 4.0 International License. 
Table 2 Table University of Sindh (UOS)

\begin{tabular}{|c|c|c|c|c|c|c|c|c|}
\hline \multicolumn{9}{|c|}{ University of Sindh (UOS) } \\
\hline $\begin{array}{l}\text { Establish } \\
\text { ment year }\end{array}$ & $\begin{array}{l}\text { No } \\
\text { of } \\
\text { facu } \\
\text { lty }\end{array}$ & $\begin{array}{l}\text { No of } \\
\text { Dept. }\end{array}$ & $\begin{array}{c}\text { Is } \\
\text { Entepreneurs } \\
\text { hip offered } \\
\text { as } \\
\text { specialized } \\
\text { subject? }\end{array}$ & $\begin{array}{c}\text { Is } \\
\text { Entrepreneur } \\
\text { ship offered } \\
\text { as a core } \\
\text { Course? }\end{array}$ & $\begin{array}{l}\text { ORIC } \\
\text { Dept. }\end{array}$ & $\begin{array}{c}\text { No of } \\
\text { incubators }\end{array}$ & $\begin{array}{l}\text { No of } \\
\text { Start- } \\
\text { up }\end{array}$ & $\begin{array}{l}\text { No of } \\
\text { Patents }\end{array}$ \\
\hline 1947 & 9 & 60 & No & $\begin{array}{c}\text { Yes } \\
\text { Entrepreneur } \\
\text { ship course } \\
\text { offered in } 8 \\
\text { departments } \\
\text { of bachelors }\end{array}$ & $\begin{array}{l}\text { Yes } \\
\text { Availa } \\
\text { ble }\end{array}$ & $\begin{array}{c}\text { The First ever } \\
\text { technology } \\
\text { incubation } \\
\text { center (TIC) }\end{array}$ & No & No \\
\hline
\end{tabular}

$\begin{array}{lc}\text { Table } 3 \text { Table University of Sindh (UOS) } \\ 1 & \text { BS/MS Commerce } \\ 2 & \text { Banking Finance } \\ 3 & \text { BS/MS Business Administration } \\ 4 & \text { Department of Electronic Engineering } \\ 5 & \text { BS Sociology } \\ 6 & \text { MS of Art Sociology } \\ 7 & \text { BS Public administration } \\ 8 & \text { M.A Women Development Studies }\end{array}$

The University of Sindh (UOS) has a total of 60 departments, but Table 2 shown only 8 departments they offer an entrepreneurship course. When comparing Mehran University of Engineering \& Technology to Sindh University, we can see that Mehran University of Engineering and Technology is more conscious about entrepreneurship. However, Sindh university just 8 departments offered entrepreneurship courses. The results shown Mehran University of engineering and technology are more entrepreneurial in their approach.

Source:

Sindh University (2021) .Prospectus. URL:

https://usindh.edu.pk/

https://admission.usindh.edu.pk/eportal_resource/files/Prospectus_2021.pdf

Table 3. Liaquat University of Medical and Health Science

\begin{tabular}{|c|c|c|c|c|c|c|c|c|}
\hline \multicolumn{9}{|c|}{ Liaquat University of Medical and Health Science (LUMHS) } \\
\hline $\begin{array}{l}\text { Establishme } \\
\text { nt year }\end{array}$ & $\begin{array}{l}\text { No } \\
\text { of } \\
\text { facul } \\
\text { ty }\end{array}$ & $\begin{array}{l}\text { No of } \\
\text { Dept. }\end{array}$ & $\begin{array}{c}\text { Is } \\
\text { Entepreneursh } \\
\text { ip offered as } \\
\text { specialized } \\
\text { subject? }\end{array}$ & $\begin{array}{l}\text { Is } \\
\text { Entrepreneurs } \\
\text { hip offered as } \\
\text { a core Course? }\end{array}$ & $\begin{array}{l}\text { ORIC } \\
\text { Dept. }\end{array}$ & $\begin{array}{l}\text { No of } \\
\text { incubators }\end{array}$ & $\begin{array}{l}\text { No of } \\
\text { Start-up }\end{array}$ & $\begin{array}{l}\text { No of } \\
\text { Patents }\end{array}$ \\
\hline 1881 & 5 & 16 & No & $\begin{array}{l}\text { Not offered to } \\
\text { any Depts. }\end{array}$ & $\begin{array}{l}\text { Yes } \\
\text { Availab } \\
\text { le }\end{array}$ & No & No & N0 \\
\hline
\end{tabular}

Table 3 shows that the Liaquat University of medicine and health has 10 departments, none of them offered an entrepreneurship course. There is a lack of awareness regarding entrepreneurship

While most students recognize the importance of education, they may limit their studies to the more conventional topics of History, science, English, mathematics, foreign language, and the arts. Many students, on the other hand, understand that entrepreneurship courses supplement their education by teaching collaboration skills, communication, time management, and negotiation, among other things. Indeed, entrepreneurship is more than a subject; it is a mindset that pushes people to solve problems swiftly and creatively in order to create value. Entrepreneurship education is equally important for all departments for preparing the students for their future.

Prior studies Wardana et al. (2020)discovered that entrepreneurial education offers basic entrepreneurship knowledge that prepares students to be competent and experts in the new business launch process. The results offer new understandings into Pakistani entrepreneurial education/ course, assisting business students in gaining This work is licensed under a Creative Commons Attribution-ShareAlike 4.0 International License. 
information and experience in starting and managing a new firm. Entrepreneurial education teaches students how to recognize and take advantage of market opportunities. It encourages students to get more information, abilities, and inspiration in order to boost their entrepreneurial mindset (Yuan et al., 2021).

\section{Source:}

LUMHS (2021).prospectus.URL:

https://lumhs.edu.pk/admissions/technologies/propectus20-21.pdf

https://www.lumhs.edu.pk/home/

\section{Conclusion}

Pakistan, being a developing country, faces certain issues like unemployment, low economic growth and poverty. Entrepreneurship is the one of the solution to reduce these problems. A small business which is formed by persons with an entrepreneurial mindset, which motivates them to start firms on a high level, produce wealth and the most the jobs. People who are exposed to entrepreneurship are more likely to rapid their self because they have more opportunities to implement higher self-value, creative freedoms and have adequate control over their life. As a result, higher educational institutions in Pakistan must devote greater emphasis to entrepreneurship education to provide opportunities for early people to establish their own businesses, which would reduce unemployment, create jobs for others and enhance the growth of our country.

Entrepreneurship has become an important part of the today's educational system. Entrepreneurial education must be introduced as a compulsory subject and implemented within the present educational system. This course teaches not only the business area, but also other fields that should be included in the educational system as a compulsory subject. All over the world universities are becoming gradually more entrepreneurial, not only offering educational programs, but also seeing themselves as main players within the Social and economic development and innovation ecosystem Etzkowitz (2003).In Pakistan, entrepreneurial education is still an unfamiliar concept. Entrepreneurship education in most universities and colleges is still limited to one or two disciplines offered in undergraduate and postgraduate degrees. The results of this study indicated the public universities of the Jamshoro higher education city, just one core course on entrepreneurship was offered to some departments. Furthermore entrepreneurship programs were extremely rare. After review and reading existing literature, articles, official reports of universities the results show in many other countries like the USA, Europe all are starting to transform their universities into entrepreneurial university. Looking forwards, both the public and private sectors must create an atmosphere that encourages overseas entrepreneurs to come to Pakistan and start a firm. Pakistan, like model nations such as the United States, the United Kingdom, and China, must develop a road plan for entrepreneurial activity, since this is one of the methods to reduce poverty and unemployment.

\section{References}

Amanuddin Shamsuddin, Thivia Kumaran Ganesan, Nur Syazwani Diyana Che Rosli, Vishu Kurup Mathaven, and Muhammad Zahier Zawari. 2018. "Factors Influence Graduates in Becoming Entrepreneurs Among Accounting Students in Malaysian University." International Journal of Business, Economics and Law 15(4):87-98.

Andersen, J. P., Prause, J., \& Silver, R. C. (2011). 2011. “A Step-by-Step Guide to Using Secondary Data for Psychological Research." Social and Personality Psychology Compass 5(1):56-75.

Anjum, T., Ramzani, S. R., \& Nazar, N. 2020. "A Study of Business Students from Universities of Pakistan." Antecedents of Entrepreneurial Intentions : 1(2):72-88.

Anon. 2005. Entrepreneurship Education System in Higher Education Institutions: A Comparison between Malaysia and Thailand. Paper Presented at 5th Comparative Education Society of Asia Biennial Conference 2005. malaysia: Universiti Kebangsaan Malaysia.

Asghar, Muhammad Zaheer. 2019. "A Study of the Entrepreneurship Education Curriculum Adaptation Process among In-Service Vocational Education Teachers.” Pp. 105-29 in The Role and Impact of Entrepreneurship Education. Edward Elgar Publishing.

Boslaugh, S. 2007. Secondary Data Sources for Public Health: A Practical Guide. New York,: NY: Cambridge.

Donckels, R. 1991. "'Education and Entrepreneurship Experience from Secondary and Universityeducation in Belgium." Journal of Small Business and Enterprise, 9(1):59-68.

Drucker, P. F. 1985. Innovation and Entrepreneurship: Practice And Principles. Harper and Row: New York.

Etzkowitz, Henry. 2003. "Innovation in Innovation: The Triple Helix of University-Industry-Government Relations.” Social Science Information 42(3):293-337. doi: 10.1177/05390184030423002.

Fayolle, Alain, Benoît Gailly, and Narjisse Lassas-Clerc. 2006. "Assessing the Impact of Entrepreneurship Education Programmes: A New Methodology.” Journal of European Industrial Training 30(9):701-20. doi: 10.1108/03090590610715022.

This work is licensed under a Creative Commons Attribution-ShareAlike 4.0 International License. 
Freytag, Andreas, and Roy Thurik. 2010. "Introducing Entrepreneurship and Culture." Pp. 1-8 in Entrepreneurship and Culture. Berlin, Heidelberg: Springer Berlin Heidelberg.

Gist, M.E. and Mitchell, T. R. 1992. "'Self-Efficacy: A Theoretical Analysis of Its Determinants Andmalleability.," Academy of Management Review 17(2):183-211.

Hitt, Michael A., and Timothy S. Reed. 2000. "Entrepreneurship in the New Competitive Landscape.” Pp. 23-48 in Entrepreneurship as Strategy: Competing on the Entrepreneurial Edge Entrepreneurship as strategy: Competing on the entrepreneurial edge. 2455 Teller Road, Thousand Oaks California 91320 United States: SAGE Publications, Inc.

Iswati, Luluk, and Saptin Dwi Setyo Hastuti. 2021. "Evaluating On-Going ESP Courses at Two Higher Education Institutions: Students' Perspectives.” in Proceedings of the 4th International Conference on Sustainable Innovation 2020-Social, Humanity, and Education (ICoSIHESS 2020). Paris, France: Atlantis Press.

Johannisson, B. 1991. “University Training for Entrepreneurship: A Swedish Approach.”" Entrepreneurship and Regional Development 3(1):67-82.

Khan, S. A. 2008. Significance of Entrepreneurial Education in Higher Education. Paper Presented at the 8th International Entrepreneurship Forum (IEF). Ahmadabad,india: International Conference on Creativity and Entrepreneurship.

Kirkley, W. W. 2017. “Cultivating Entrepreneurial Behavior: Entrepreneurship Education in Secondaryschools.” Asia Pacific Journal of Innovation and Entrepreneurship, 11(1):17-37.

Kirkley, William W. 2016. "Creating Ventures: Decision Factors in New Venture Creation.” Asia Pacific Journal of Innovation and Entrepreneurship 10(1):151-67. doi: 10.1108/APJIE-12-2016-003.

Klapper, Leora F., and Inessa Love. 2004. "Corporate Governance, Investor Protection, and Performance in Emerging Markets.” Journal of Corporate Finance 10(5):703-28. doi: 10.1016/S0929-1199(03)00046-4.

Kroon, J., and S. Meyer. 2001. "The Role of Entrepreneurship Education in Career Expectations of Students." South African Journal of Higher Education 15(1). doi: 10.4314/sajhe.v15i1.25379.

Krueger, B. A. \& Lindahl, M. 2001. “Education for Growth: Why and for Whom?” Journal of Economic Literature 39:1101-36.

Kuratko, D. F. 2005. "The Emergence of Entrepreneurship Education: Development, Trends and Challenges." Entrepreneurship Theory and Practice 29(5):577-98.

Kuttim, M., Kallaste, M., Venesaar, U. and Kiis, A. 2014. “"Entrepreneurship Education at Universitylevel and Students'entrepreneurial Intentions." Procedia-Social and Behavioral Sciences 110:658-68.

Marcati, A., Guido, G., Peluso, A.M. 2008. “The Role Of SME Entrepreneurs' Innovativeness And Personality In The Adoption Of Innovations.” Research Policy 37(9):1579-1590.

Nabi, G. and Holden, R. 2008. "Intentions, Education and Training", Education and Training." Graduate Entrepreneurship 50(7):545-55.

Noel, T. W. 2001. “"Effects of Entrepreneurial Education on Intent to Open a Business." Frontiers OfEntrepreneurship Research, Babson Conference Proceedings.

Noor, Shaista, Filzah Md. Isa, and Leilanie Mohd Nor. 2020. "Identifying the Current Trends of Entrepreneurial Education in Pakistani Higher Education Institutions." Sains Humanika 12(3). doi: 10.11113/sh.v12n3.1642.

Ratten, Vanessa, and Paul Jones. 2021. "Entrepreneurship and Management Education: Exploring Trends and Gaps.” The International Journal of Management Education 19(1):100431. doi: 10.1016/j.ijme.2020.100431.

Schulte, P. 2004. "The Entrepreneurial University: A Strategy for Institutional Development." Higher Education in Europe. 29(2):187-91.

Setiawan, William Vincent, Andi Marlin Fattah, and Angga Puspitaningrum. 2019. "The Challenges of Student in Indonesia after College Graduates with Career Choice Start: Evidence from Ten Private Universities in Jakarta." The Winners 20(2):61. doi: 10.21512/tw.v20i2.5674.

Shah, Naimatullah, and Bahadur Ali Soomro. 2017. "Investigating Entrepreneurial Intention among Public Sector University Students of Pakistan.” Education + Training 59(7/8):841-55. doi: 10.1108/ET-11-2016-0168.

Śledzik, Karol. 2013. "Schumpeter's View on Innovation and Entrepreneurship." SSRN Electronic Journal. doi: $10.2139 /$ ssrn.2257783.

Souitaris, V., Zerbinati, S. and Al-Laham, A. 2007. “"Do Entrepreneurship Programmes Raiseentrepreneurial Intention of Science and Engineering Student? The Effect of Learning, Inspirationand Resource." Journal of Business Venturing 22(4):566-91.

Tanveer, Muhammad and Karim, Asif Mahbub Dr. 2019. "The Use of Performance Measurement in Universities of Pakistan".

Wardana, Ludi Wishnu, Bagus Shandy Narmaditya, Agus Wibowo, Angga Martha Mahendra, Nyuherno Aris Wibowo, Gleydis Harwida, and Arip Nur Rohman. 2020. "The Impact of Entrepreneurship Education and Students’ Entrepreneurial Mindset: The Mediating Role of Attitude and Self-Efficacy.” Heliyon 6(9):e04922. doi: 10.1016/j.heliyon.2020.e04922. 